\title{
Methane Occurrence in Groundwater of South-Central New York State, 2012: Summary of Findings
}

\section{Introduction}

A survey of methane in groundwater was undertaken to document methane occurrence on the basis of hydrogeologic setting within a glaciated 1,810-square-mile area of south-central New York (fig. 1) that has not seen shale-gas resource development. The adjacent region in northeastern Pennsylvania has undergone shale-gas resource development from the Marcellus Shale.

Well construction and subsurface data were required for each well sampled so that the local hydrogeologic setting could be classified (fig. 2). All wells were also at least 1 mile from any known gas well (active, exploratory, or abandoned). Sixty-six domestic wells and similar purposed supply wells were sampled during summer 2012. Field water-quality characteristics (pH, specific conductance, dissolved oxygen, and temperature) were measured at each well, and samples were collected and analyzed for dissolved gases, including methane and short-chain hydrocarbons. Carbon and hydrogen isotopic ratios of methane were measured in 21 samples that had at least 0.3 milligram per liter $(\mathrm{mg} / \mathrm{L})$ methane.
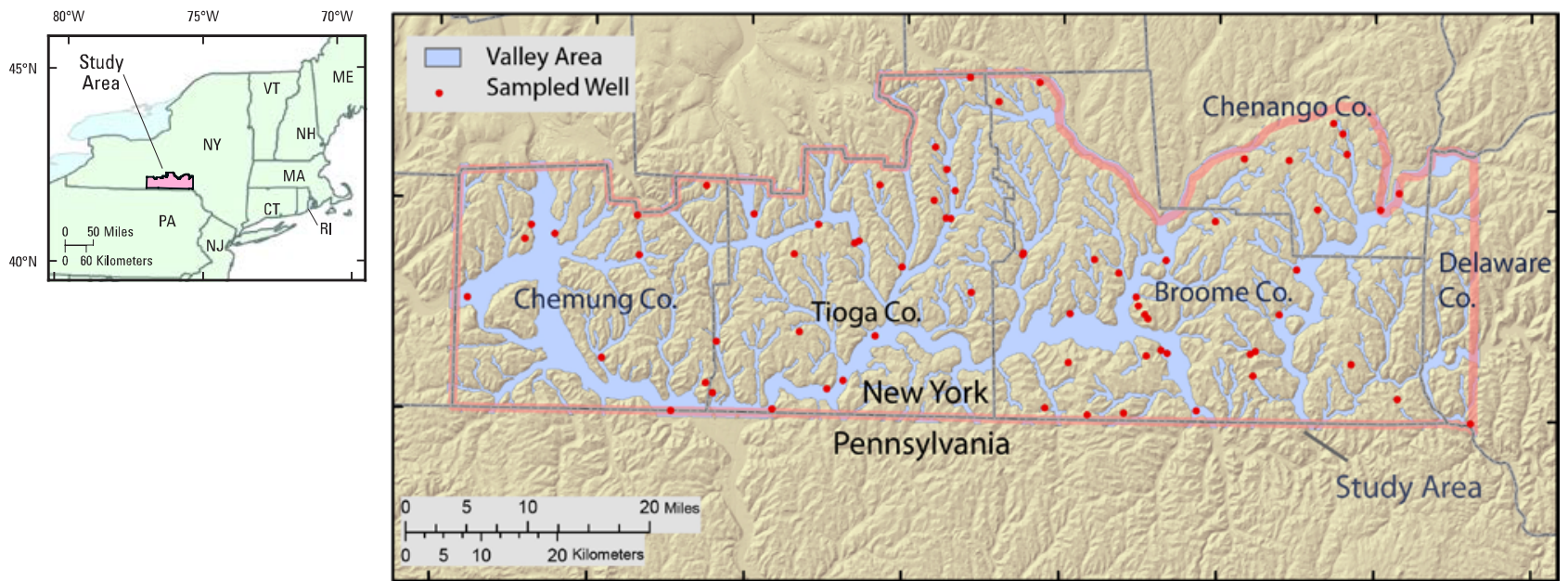

Figure 1. Map showing locations of valley areas and sampled water wells in south-central New York; adapted from Heisig and Scott (2013, fig. 4).

\section{Hydrogeologic Setting Classification}

Each well sampled was classified by the hydrogeologic setting (fig. 2) from which the well draws water. The major setting components are as follows:

- Topographic position (valley or upland)

- Whether or not the groundwater is confined (isolated from the atmosphere) by glacial deposits

- Type of aquifer the well is completed in (sand and gravel or bedrock)

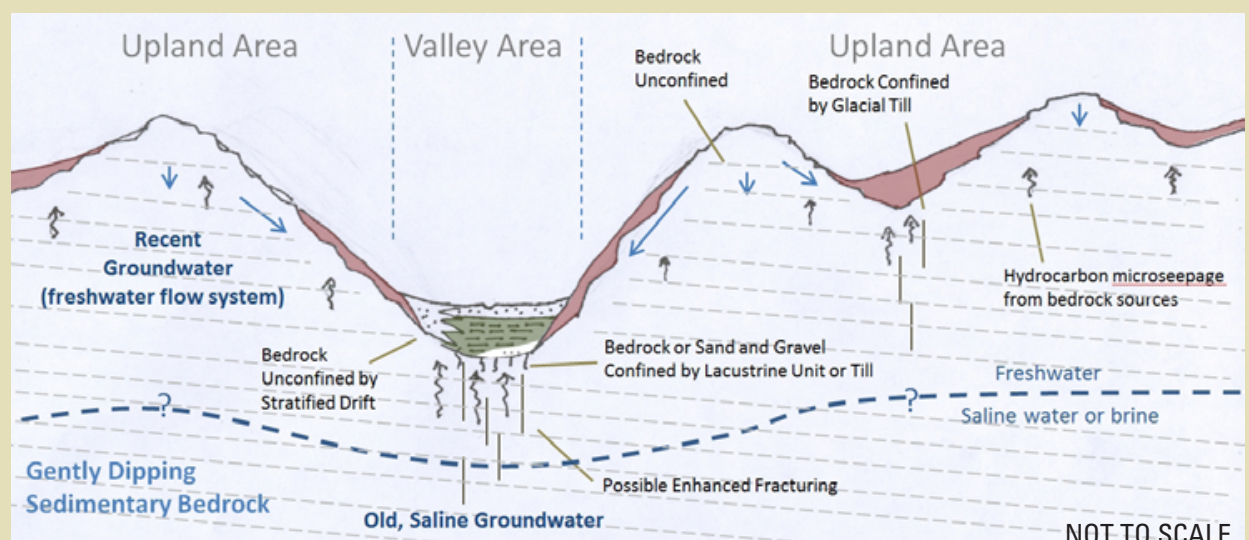

Figure 2. Simplified conceptual diagram of hydrogeologic settings in south-central New York adapted from Heisig and Scott (2013, fig. 10). 


\section{How Much Methane Was Found?}

Results of sampling indicate that occurrence of methane in groundwater of the region is common-greater than or equal to $0.001 \mathrm{mg} / \mathrm{L}$ in 78 percent of the groundwater samples (fig. 3). Concentrations of methane ranged over five orders of magnitude. Methane concentrations at which monitoring or mitigation is indicated (greater than or equal to $10 \mathrm{mg} / \mathrm{L}$ ) were measured in 15 percent of the samples.

Methane Concentration, in Milligrams per Liter

\begin{tabular}{|l|c|c|c|c|c|}
\multicolumn{1}{|c}{0.001} & 0.1 & 1.0 & 10 & 28 & 55 \\
\hline $\mathbf{2 1 . 5} \%$ & $\mathbf{4 3 . 1} \%$ & $\mathbf{9 . 2} \%$ & $\mathbf{1 0 . 8} \%$ & $\mathbf{9 . 2} \%$ & $\mathbf{6 . 2} \%$ \\
\hline
\end{tabular}

Figure 3. Strip chart showing methane concentrations in samples collected at water wells in south-central New York.

\section{Where Was Methane Found?}

Methane concentrations greater than $0.1 \mathrm{mg} / \mathrm{L}$ were associated with specific hydrogeologic settings (fig. 4). At concentrations between 0.1 and $28 \mathrm{mg} / \mathrm{L}$, occurrence was associated with (1) confined conditions (confinement of groundwater by glacial deposits) in valleys and to a lesser extent in uplands, and (2) completion of bedrock wells in valleys. The highest methane concentrations (greater than or equal to $28 \mathrm{mg} / \mathrm{L}$ ) were limited to wells completed in bedrock and confined by glacial deposits in valleys.

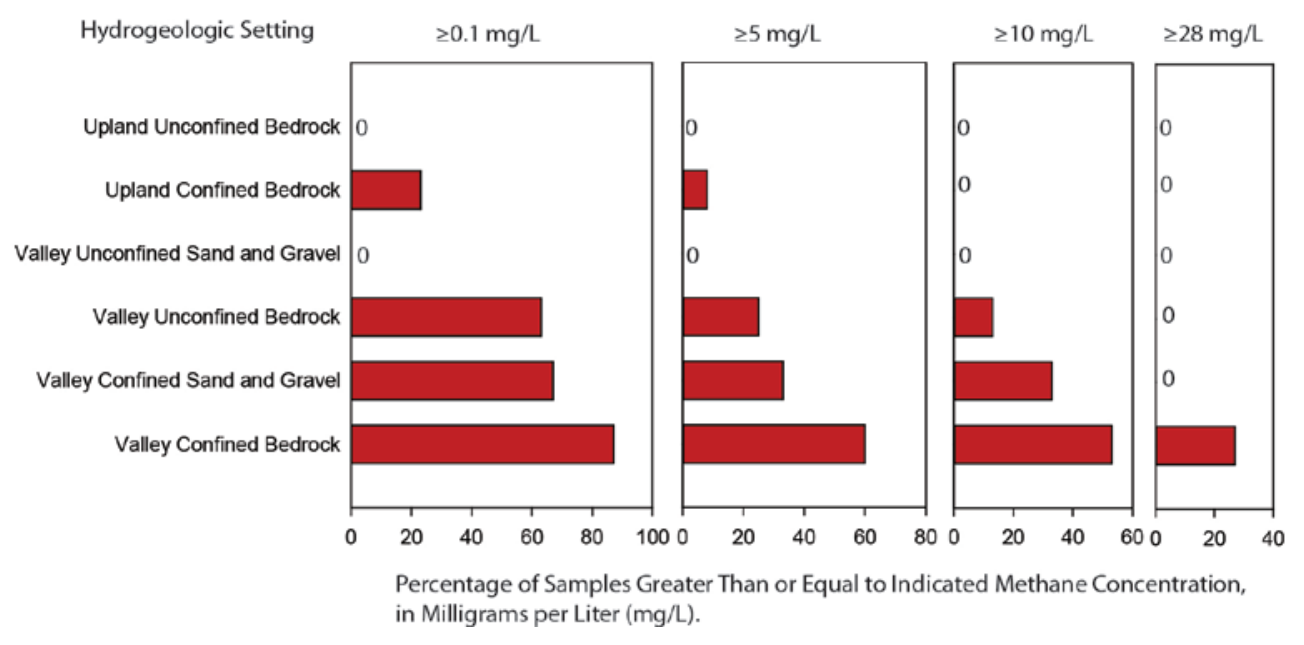

Figure 4. Graphs showing percentage of groundwater samples where methane concentrations were met or exceeded among different hydrogeologic settings in south-central New York.

\section{What Are the Origins of the Methane?}

The origin of methane differed between the major hydrogeologic settings, as indicated by isotopic signatures of carbon and hydrogen. Methane is formed by either thermogenic or microbial processes or some mixture of the two.

- Thermogenic methane is generated by heat and pressure acting on deeply buried organic-rich rocks. Methane in valley wells (completed in bedrock or confined by glacial deposits) was predominantly thermogenic in origin. This methane is likely a result of close vertical proximity to underlying methanebearing saline groundwater and brine and possibly as a result of enhanced bedrock fracture permeability beneath valleys.

- Microbial methane is produced by bacteria that utilize carbon dioxide or organic matter in bedrock in highly reducing environments (no oxygen) within the groundwater flow system (long residence time groundwater). Methane from a few upland well samples mostly indicated a microbial origin.
- Mixed origin methane was indicated in some water samples from wells in valley settings. This may reflect the close proximity of regional groundwater flow and underlying saline water and brine in valley areas (fig. 2).

\section{Significance of Findings}

This characterization of groundwater methane shows the importance of subsurface information (hydrogeology and well construction) in understanding methane occurrence and provides an initial conceptual framework that can be utilized in the investigation of stray gas in south-central New York.

\section{Reference Cited}

Heisig, P.M., and Scott, Tia-Marie, 2013, Occurrence of methane in groundwater of south-central New York State, 2012-Systematic evaluation of a glaciated region by hydrogeologic setting: U.S. Geological Survey Scientific Investigations Report 2013-5190, 32 p. (Also available at http://dx.doi.org/10.3133/ sir20135190.)

\section{Director}

U.S. Geological Survey

New York Water Science Center

425 Jordan Road

Troy, NY 12180-8349

http://ny.water.usgs.gov
For more information:

Visit the project Web site at

http://ny.cf.er.usgs.gov/nyprojectsearch/projects/LK00-Meth-00.html

or contact

Paul M. Heisig

(518) 285-5648

pmheisig@usgs.gov by Paul Heisig and Tia-Marie Scott

ISSN 2327-6932 (online)

http://dx.doi.org/10.3133/fs20133118 